\title{
Enzymatic hydrolysis of lactose in concentrates of reconstituted demineralized whey, intended for ice cream production
}

\author{
Tetiana Osmak ${ }^{1}$, Stanisław Mleko², Oksana Bass ${ }^{1}$, \\ Artur Mykhalevych ${ }^{1}$, Uliana Kuzmyk ${ }^{1}$ \\ 1 - National University of Food Technologies, Kyiv, Ukraine \\ 2 - University of Life Sciences in Lublin, Lublin, Poland
}

Keywords:

Whey

Lactose

Enzymolysis

B-galactosidase

Lactobacillus

acidophilus

Ice cream

\section{Article history:}

Received 14.07.2020

Received in revised

form 26.11.2020

Accepted 30.06.2021

Corresponding

author:

Uliana Kuzmyk

E-mail:

ukuzmik@gmail.com

DOI:

$10.24263 / 2304-$

974X-2021-10-2-6

\section{Abstract}

Introduction. The feasibility of using fermented concentrates of reconstitutd demineralized sweet whey as a source of whey proteins and monosaccharides in ice cream was proved.

Materials and methods. Physicochemical parameters of reconstituted fermented and unfermented concentrates of demineralized sweet whey with dry matter content from 10 to $40 \%$ were studied. The lactose content was determined by the accelerated colorimetric method, water activity - on the water activity analyzer.

Results and discussion. Rational regimes of enzymatic hydrolysis of lactose in concentrates of reconstituted demineralized sweet whey with dry matter content from 10 to $40 \%$ are temperature of $40-43{ }^{\circ} \mathrm{C}$ and a $\mathrm{pH}$ of $6.1-6.6$, the recommended dose of liquid enzyme preparation GODO-YNL2, obtained from the yeast Kluyveromyces lactis, for concentrates with a lactose content of $7.5-30.0 \%$ ranges from 0.1 to $0.4 \%$. The duration of enzymatic hydrolysis under these conditions for $4 \pm 2 \mathrm{~h}$ ensures the degree of lactose hydrolysis not less than $70 \%$. In order to increase the degree of lactose hydrolysis simultaneously with the enzyme preparation in certain quantities single-strain lyophilized probiotic culture $\ll L$. acidophilus $L Y O 5 O D C U-S »$ was used.

During the first 4 hours of incubation, the active acidity of the whey concentrates samples reaches values not lower than $\mathrm{pH}=5.7-$ 5.9. At the specified acidity, the enzyme preparation GODO-YNL2 shows sufficient activity. The presence of lactose hydrolysis products to some extent stimulates the development of $L$. acidophilus. Due to the joint hydrolyzing action of enzyme and starter culture preparations for 6-8 hours, the degree of lactose hydrolysis can be achieved at the level of $80-85 \%$.

The prospect of further research is the development of scientifically sound ice cream formulations based on hydrolyzed concentrates of reconstituted fermented whey. Ice cream enriched with whey proteins and probiotic culture of $L$. acidophilus will also have a lower content of disaccharides - sucrose and lactose.

Conclusions. The possibility of increasing the efficiency of lactose enzymolysis in concentrates of reconstituted demineralized whey to $80-85 \%$ by combining the specific action of the enzyme preparation GODO-YNL2 and starter based on L. acidophilus has been proved. The product of enzymolysis is of technological interest as a multifunctional ingredient in ice cream. 


\section{Introduction}

Ice cream with a higher content of milk proteins is usually enriched with casein and caseinates, whey protein concentrates, as well as dry dairy products (Nadtochij et al., 2016; Polishchuk et al., 2020). It was proved the possibility of increasing the protein content by 30 $90 \%$ in ice cream with a mass fraction of $10.5 \%$ fat by adding concentrates of whey proteins and milk proteins (Patel, 2006), but it significantly increases the cost of the finished product at its rather high-fat content. At the same time, reducing the caloric content of ice cream by limiting its fat content to not more than $5 \%$ is one of the urgent tasks in the field of its production. Decreased fat content or its absence in ice cream leads to defects of consistency (Goff and Hartel, 2013). Usually, problems with the formation of organoleptic quality indicators of low-fat ice cream are solved by using polysaccharides and products of their chemical modification or destruction (Azari-Anpar et al., 2017). These compounds only thicken the aqueous phase and do not affect the nutritional value of the product. Instead, whey proteins have a unique ability to mask the absence or low-fat content in ice cream (El-Zeini et al., 2016), which allows increasing the biological value of the product and ensure its high quality.

The cheapest source of biologically complete whey proteins in ice cream is condensed and dry whey. However, whey contains up to 70-75\% of lactose from the total dry matter content, the excess of which in ice cream causes its excessive crystallization (Livney et al., 2007). Reducing the lactose content or its exclusion from the composition of ice cream by enzymatic hydrolysis prevents defects of consistency during storage of the hardened product (Özdemir et al., 2018; Chauhan et al. 2010). The products of lactose hydrolysis are also characterized by an increased degree of sweetness, which makes it possible to reduce the sugar content in ice cream composition. Partial hydrolysis of lactose can be achieved by incubating ice cream mixtures with lactic acid bacteria (Borovik et al., 2014). However, the combination of both methods of lactose enzymolysis in whey concentrates with the simultaneous use of enzyme and starter culture preparations has not been studied, which confirms the need for further study of this issue.

It is known that reconstituted whey is not inferior to milk as a nutrient medium for lactobacilli, and the rate of enzymatic reaction depends only on the initial lactose content in the dairy system (Lisak et al., 2011; Drgalic et al., 2005; Stehlik-Tomas et al., 2001). This gives rise to choose reconstituted whey not only as a source of protein but also lactose for its microbial fermentation.

Quite a high content of salts in the whey (up to $0.6-0.8 \%$ - in fresh, up to $8.5 \%$ - in dry) can also affect the quality of ice cream - its taste and texture (Goff and Hartel, 2013). The addition of 10 to $25 \%$ of dry whey to the ice cream reduces the cryoscopic temperature of the mixtures by more than $0.55^{\circ} \mathrm{C}$, which significantly impairs the shape stability of the ice cream (Robert et al., 2003). Therefore, it is advisable to use for the production of whey ice cream reconstituted concentrates of demineralized whey with a mass fraction of dry matter, which corresponds to their content in the finished product (20-40\%).

At the same time, it is known that the most efficient whey hydrolysis occurs at a degree of demineralization of $70 \%$. Exceeding this value reduces the content of magnesium and manganese ions in the whey, which activates the enzymatic activity of $\beta$-galactosidase (Sokolovskaja et al., 2017). Thus, hydrolyzed whey concentrates with a degree of demineralization of $70 \%$ are promising in the composition of ice cream, as they will reduce the need for sugar, prevent consistency defects and increase the nutritional value of lowlactose ice cream (Barukčić and Božanić, 2008). 


\section{— Food Technology —}

The purpose of the research is to study the patterns of the process of lactose hydrolysis in reconstituted concentrates of sweet demineralized whey, intended for the production of ice cream with higher content of whey proteins and low lactose content.

So it is necessary to solve the following tasks:

- Choose a technologically feasible way to enrich ice cream with milk proteins;

- To determine the rational modes of enzymatic hydrolysis of lactose in concentrates of demineralized sweet whey;

- To check the possibility of lactose enzymolysis with simultaneous use of enzyme and starter culture preparations;

- To determine the possibility of partial replacement of sugar by hydrolyzed whey concentrates in ice cream composition.

\section{Materials and methods}

\section{Materials}

Demineralized whey powder was selected for the study, which contains in terms of dry matter: ash - not more than $2.5 \%$, lactose - not less than $79 \%$, protein - not less than $10.7 \%$. The solubility index of dry demineralized whey is $0.5 \mathrm{~cm}^{3}$ of the raw precipitate.

As an enzyme preparation, a liquid preparation of $\beta$-D-galactosidase hydrolase (lactase) with the trade name GODO-YNL2 (Danisko, Denmark) was used, which is a producer of selection strains of Kluyveromyces lactis. Under standard conditions of milk hydrolysis for $24 \mathrm{~h}$ at a temperature of $4.4-7.2{ }^{\circ} \mathrm{C}$, the recommended amount of the preparation GODOYNL2 (containing 10\% $\beta$-galactosidase) is $100 \mathrm{~g}$ per 100 liters of milk.

For incubation of fermented samples with residual lactose content was used starter preparation «L. acidophilus LYO 50 DCU-S» (Danisko, Denmark), which is a single-strain lyophilized probiotic culture with the recommended dose of $5 \mathrm{~g}$ per 100 liters of milk.

\section{Samples and their preparation}

Dry whey was reconstituted in drinking water at a temperature of $40-45^{\circ} \mathrm{C}$, the obtained concentrates with a mass fraction of dry matter from 10 to $40 \%$ were filtered, pasteurized at a temperature of $85-88{ }^{\circ} \mathrm{C}$ for $3-5 \mathrm{~min}$, cooled to a temperature of $40-43{ }^{\circ} \mathrm{C}$ (temperature range acceptable for enzymolysis with various preparations) and fermented with the preparation GODO-YNL2 and starter based on the starter preparation «L. acidophilus LYO $50 \mathrm{DCU}-S$ » for different combinations, according to the schemes below.

The degree of lactose hydrolysis was determined by variable modes of fermentation in concentrates of reduced demineralized sweet whey with a mass fraction of dry matter from 10 to $40 \%$. The mass fraction of the enzyme preparation was varied in the range from 0.1 to $0.4 \%$, the duration of the fermentation process - from 1 to 10 hours.

The following schemes of fermentation process were adopted:

- Scheme 1. Fermentation of whey concentrates with the enzyme preparation GODOYNL2;

- Scheme 2. Fermentation of whey concentrates with enzyme preparation GODO-YNL2 and starter preparation «l. Acidophilus lyo $50 \mathrm{dcu}-s »$. 
With the simultaneous application of the enzyme GODO-YNL2 and the starter preparation, it is assumed that during the lag phase of $L$. acidophilus development (2-4 h) the enzyme should have time to detect hydrolytic activity at active acidity $\mathrm{pH} \geq 5.7$.

\section{Methods}

\section{Method for determining lactose content}

The lactose content was determined by the accelerated colorimetric method (Teles et al., 1978) by changing the color of whey samples, which occurs due to the interaction between phenol, sodium hydroxide, picric acid, sodium bisulfide with lactose.

\section{Methods for determining active and titrated acidity}

The active acidity index was measured on a $\mathrm{pH}$-meter «pH-150 MA» with a combined glass electrode «ESC 10601/4» (Tomovska et al., 2016).

Measurement of titratable acidity was carried out in accordance with a generally known method (Tomovska et al., 2016).

\section{Method for determining water activity}

Water activity was determined in whey concentrates before and after fermentation on a water activity analyzer "HygroLab 2" (Rotronic, Switzerland) at a temperature of $20{ }^{\circ} \mathrm{C}$ in the measurement range 0-1 Aw (0-100\% rh) (Kuzmyk et al., 2021).

The degree of hydrolysis was expressed as a percentage, according to the lactose content of the fermented samples relative to its initial content (Livney Y. et al., 2007).

\section{Statistical analysis}

Data were expressed as means \pm standard deviations for triplicate determination. Statistical analysis was performed using Microsoft Excel 2007. Differences were considered to be significant at a validity of $\alpha=0.95$.

\section{Results and discussion}

\section{Activity of the enzyme preparation for the lactose hydrolysis in reconstituted whey concentrates}

According to scheme 1 of the fermentation process, the above, tested the effectiveness of the enzyme preparation GODO-YNL2 for the lactose hydrolysis in whey concentrates with a mass fraction of dry matter from 10 to $40 \%$. The lactose content in the samples, respectively, ranged from 7.7 to $30.8 \%$. The active acidity of the whey concentrates ranged from $6.6 \pm 0.1$ ( $10 \%$ dry matter) to $6.1 \pm 0.1$ (40\% dry matter).

In table 1 shows the values of the degree of lactose hydrolysis with variable content and duration of the process. The degree of lactose hydrolysis, not less than $70 \%$ (the corresponding values are highlighted in the table with a light gray background), and the degree of lactose hydrolysis above $75 \%$ (moderately gray background) were considered high. 
According to the results of the study (Table 1), a significant effect on the degree of lactose hydrolysis in variable parameters of this process (the content of the enzyme preparation and the duration of fermentation) was confirmed (Rosolen et al., 2015).

Table 1

Degree of lactose hydrolysis (\%) in concentrates of reconstituted demineralized sweet whey of different dry matter content with the introduction of the enzyme preparation

$(\mathrm{P} \geq \mathbf{0 . 9 5} ; \mathrm{n}=\mathbf{3})$ *

\begin{tabular}{|c|c|c|c|c|c|c|}
\hline \multirow{2}{*}{$\begin{array}{c}\text { Content of } \\
\text { the enzyme } \\
\text { preparation, \% }\end{array}$} & \multicolumn{6}{|c|}{ Duration of fermentation, $h$} \\
\hline & 1 & 2 & 4 & 6 & 8 & 10 \\
\hline \multicolumn{7}{|c|}{ Mass fraction of dry matter $10 \%$ (mass fraction of lactose $7.7 \%$ ) } \\
\hline 0,1 & $34,5 \pm 1,1$ & $55,1 \pm 1,8$ & $71,0 \pm 1,8$ & $73,1 \pm 2,0$ & $74,2 \pm 2,0$ & $75,0 \pm 2,0$ \\
\hline 0,2 & $45,3 \pm 1,3$ & $71,3 \pm 2,0$ & $72,5 \pm 1,9$ & $74,0 \pm 2,1$ & $75,1 \pm 2,5$ & $76,2 \pm 2,4$ \\
\hline 0,3 & $57,0 \pm 2,0$ & $73,0 \pm 2,2$ & $74,5 \pm 2,1$ & $75,2 \pm 2,5$ & $76,2 \pm 2,1$ & $77,0 \pm 2,3$ \\
\hline 0,4 & $70,0 \pm 2,2$ & $75,2 \pm 2,2$ & $76,2 \pm 2,2$ & $76,8 \pm 2,4$ & $77,1 \pm 2,2$ & $77,4 \pm 2,4$ \\
\hline \multicolumn{7}{|c|}{ Mass fraction of dry matter $20 \%$ (mass fraction of lactose $15.4 \%$ ) } \\
\hline 0,1 & $30,2 \pm 1,1$ & $50,8 \pm 1,9$ & $62,0 \pm 1,8$ & $69,1 \pm 2,2$ & $71,3 \pm 2,3$ & $73,5 \pm 2,0$ \\
\hline 0,2 & $42,0 \pm 1,5$ & $64,6 \pm 2,0$ & $71,1 \pm 2,1$ & $72,3 \pm 2,4$ & $73,0 \pm 2,0$ & $74,3 \pm 2,4$ \\
\hline 0,3 & $52,8 \pm 1,9$ & $71,0 \pm 2,0$ & $73,8 \pm 2,5$ & $74,2 \pm 2,0$ & $73,5 \pm 2,4$ & $75,0 \pm 2,7$ \\
\hline 0,4 & $63,8 \pm 2,0$ & $71,4 \pm 2,3$ & $75,0 \pm 2,0$ & $74,7 \pm 2,4$ & $74,9 \pm 2,0$ & $75,5 \pm 2,5$ \\
\hline \multicolumn{7}{|c|}{ Mass fraction of dry matter $30 \%$ (mass fraction of lactose $23.1 \%$ ) } \\
\hline 0,1 & $26,9 \pm 1,0$ & $47,5 \pm 1,5$ & $55,3 \pm 1,7$ & $60,3 \pm 2,5$ & $67,3 \pm 1,9$ & $72,1 \pm 2,4$ \\
\hline 0,2 & $29,8 \pm 1,2$ & $53,0 \pm 2,0$ & $61,7 \pm 2,0$ & $69,4 \pm 2,5$ & $71,5 \pm 2,2$ & $73,4 \pm 2,6$ \\
\hline 0,3 & $44,7 \pm 1,5$ & $68,1 \pm 2,1$ & $72,3 \pm 1,9$ & $72,5 \pm 2,4$ & $73,0 \pm 2,5$ & $74,5 \pm 2,2$ \\
\hline 0,4 & $58,3 \pm 1,9$ & $70,1 \pm 2,2$ & $73 \pm 2,1$ & $73,7 \pm 2,6$ & $74,3 \pm 2,2$ & $75,1 \pm 3,0$ \\
\hline \multicolumn{7}{|c|}{ Mass fraction of dry matter $40 \%$ (mass fraction of lactose $30.8 \%$ ) } \\
\hline 0,1 & $25,2 \pm 1,1$ & $42,8 \pm 1,5$ & $53,8 \pm 2,1$ & $58,4 \pm 2,0$ & $65,8 \pm 1,8$ & $70,2 \pm 2,0$ \\
\hline 0,2 & $28,0 \pm 0,9$ & $51,6 \pm 1,0$ & $59,8 \pm 2,1$ & $66,2 \pm 2,0$ & $68,9 \pm 2,2$ & $71,3 \pm 2,1$ \\
\hline 0,3 & $40,3 \pm 1,9$ & $63,7 \pm 2,0$ & $68,2 \pm 2,2$ & $71,6 \pm 2,6$ & $72,0 \pm 2,2$ & $72,6 \pm 2,0$ \\
\hline 0,4 & $50,3 \pm 1,9$ & $68,1 \pm 2,3$ & $71,3 \pm 2,0$ & $72,4 \pm 2,3$ & $73,0 \pm 2,4$ & $73,3 \pm 2,2$ \\
\hline
\end{tabular}

With the increasing duration of the process, the degree of hydrolysis increases. Moreover, in the first hours of fermentation, there is the greatest activity of the enzyme, which gradually decreases. This effect is probably due to a decrease in the lactose content in the samples and the accumulation of the content of the enzymolysis product - $\beta$-galactose, which is correlated with the known information (Mjalo et al., 2005; Hnitsevych et al., 2017). At the same time, the dynamic of the hydrolysis process of lactose is significantly influenced by the physicochemical characteristics of the samples of reconstituted demineralized whey, in particular the dry matter content. The degree of lactose hydrolysis with an increase in dry matter content from 20 to $40 \%$ is slightly reduced. This can be explained by the increase in viscosity of reconstituted whey concentrates (Sokolovskaja et al., 2017), which complicates the distribution of the enzyme in the volume of the substrate and, consequently, reduces the efficiency of the enzymatic process. 
It should also be noted that with increasing lactose content in concentrates, the need for the enzyme preparation increases with a corresponding increase in the rational duration of the enzymolysis process. Thus, to obtain the maximum hydrolytic effect for a concentrate with a mass fraction of lactose of $7.7 \%$ (10\% dry matter), the fermentation process is the shortest (1-2 hours) with a minimum need for the enzyme preparation - at $0.2 \%$. To save the enzyme by reducing its content to the recommended $0.1 \%$, the duration of hydrolysis should be extended to 4 hours. With a further gradual increase in the lactose content in concentrates to $30.8 \%$, the degree of lactose hydrolysis is not less than $70 \%$ in the shortest time for this system (4-6 hours) is possible only with an increased content of enzyme preparation - 03$0.4 \%$.

Therefore, increasing the content of the substrate requires the use of more enzyme preparation. At the same time, there are recommendations to reduce the need for enzyme preparation by increasing the dry matter content in the whey (Sokolovskaja et al., 2017), which requires further refinement for systems based on concentrated whey obtained in different ways.

The following pattern also attracts attention: a high degree of lactose hydrolysis (more than $75 \%$ ) in the samples of reconstituted demineralized whey can be achieved only with a dry matter content of not more than $30 \%$. Moreover, with increasing dry matter content in whey samples from 10 to $30 \%$, the ranges of variable parameters of the hydrolysis process to achieve the maximum degree of enzymolysis are significantly narrowed, as illustrated in Table 1.

\section{Fermentation of demineralized whey concentrates with the help of various preparations}

In order to intensify the fermentation process of lactose, the possibility of combining the hydrolyzing action of the enzyme GODO-YNL2 and the lyophilized starter « $L$. acidophilus LYO 50 DCU-S» was investigated.

For this purpose, the following regularities of the fermentation process of whey concentrates with a mass fraction of dry matter from 10 to $40 \%$ by starter on the basis of the

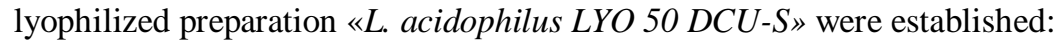

- Phase 1: within 3-4 hours the titrated acidity of fermented concentrates increased slightly - from $22-25^{\circ} \mathrm{T}(\mathrm{pH}=6.1-6.6)$ to $38-42{ }^{\circ} \mathrm{T}(\mathrm{pH}=5.7-5.9)$, which characteristic of the lag phase of bacterial development;

- Phase 2: during the next 2-3 hours there was an active increase in acidity to values of 90-100 ${ }^{\circ} \mathrm{T}(\mathrm{pH}=4.2-4.36)$;

- Phase 3: the subsequent period was characterized by a decrease in the activity of acidophilic starter with increasing titrated acidity to $110-120^{\circ} \mathrm{T}$, which is a well-known pattern and is due to the preservative action of lactic acid as a product of lactic acid fermentation on microorganisms included in compositions of starters (Sharma et al., 2017).

Since the values of active acidity below 5.5-5.6 will inhibit the enzymatic activity of the preparation GODO-YNL2, it was decided to simultaneously add to the whey concentrates enzyme preparation GODO-YNL2 and activated starter «L. acidophilus LYO $50 D C U-S$ ». The duration of the lag phase for 3-4 hours, which is observed during the incubation of whey concentrates, is sufficient for the enzyme preparation GODO-YNL2 to show its maximum activity. 
To ensure the maximum possible degree of lactose hydrolysis by the enzyme preparation within 4 hours (according to Table 1) for samples of whey concentrates was selected such it amount:

- For whey concentrate with mass fraction of dry matter $10 \%$ selected $0.1 \%$ of the preparation GODO-YNL2;

- For $20 \%$ of concentrate $-0.2 \%$;

- For $30 \%$ of concentrate $-0.3 \%$;

- For $40 \%$ of the concentrate $-0.4 \%$.

The degree of lactose hydrolysis in concentrates of reconstituted demineralized sweet whey with different dry matter content with simultaneous application of enzyme and fermentation preparations are given in table 2. Light gray background highlighted the values of the degree of lactose hydrolysis higher than $70 \%$, gray - higher than $75 \%$, dark gray higher than $80 \%$.

Table 2

Degree of lactose hydrolysis (\%) in concentrates of reconstituted demineralized sweet whey of different dry matter content with the simultaneous introduction of enzyme and starter preparations

$(\mathrm{P} \geq \mathbf{0 . 9 5} ; \mathrm{n}=\mathbf{3})^{*}$

\begin{tabular}{|c|c|c|c|c|c|c|}
\hline $\begin{array}{c}\text { Mass fraction of } \\
\text { dry matter in } \\
\text { concentrate, } \\
\text { \% }\end{array}$ & 1 & 2 & 4 & 6 & 8 & 10 \\
\cline { 2 - 8 } & & & & & & \\
\hline 10 & $34,7 \pm 1,1$ & $56,4 \pm 1,8$ & $76,2 \pm 2,2$ & $83,5 \pm 2,5$ & $86,5 \pm 2,0$ & $87,1 \pm 2,8$ \\
\hline 20 & $42,5 \pm 1,5$ & $65,1 \pm 2,3$ & $75,4 \pm 2,5$ & $81,5 \pm 1,8$ & $86,0 \pm 2,4$ & $86,9 \pm 2,5$ \\
\hline 30 & $45,0 \pm 1,8$ & $68,2 \pm 2,1$ & $73,8 \pm 2,7$ & $79,8 \pm 2,0$ & $85,9 \pm 2,3$ & $86,3 \pm 2,2$ \\
\hline 40 & $50,8 \pm 1,5$ & $68,5 \pm 2,3$ & $73,3 \pm 2,2$ & $79,0 \pm 2,0$ & $79,8 \pm 2,2$ & $84,0 \pm 2,3$ \\
\hline
\end{tabular}

The combination of hydrolyzing action of the enzyme and starter preparations allows to increase the degree of lactose hydrolysis in the composition of lactose concentrates to $80 \%$ and above. To do this, it is necessary to ensure the duration of the total hydrolytic process in concentrates with a dry matter content of $10-30 \%$ for 6-8 hours. Prolongation of the hydrolysis process to 10 hours does not lead to a significant result in terms of changes in the composition of fermented samples of whey concentrates, except for the sample with the maximum dry matter content. It should also be noted that the presence of lactose hydrolysis products to some extent stimulates the development of $L$. acidophilus bacteria, the activity of which decreases slightly over time. This is due to the increase in osmotic pressure due to the accumulation of low molecular weight products of lactose hydrolysis in concentrates of reconstituted demineralized sweet whey from 10 to $40 \%$ (Sleator and Hill, 2002).

In contrast with recent studies (Schmidt et al., 2016; Sangwan, et al., 2015), based on the use or production of enzyme monopreparations of narrow direction, revealed a symbiotic effect of the joint interaction of the enzyme and the starter of $L$. acidophilus. The revealed symbiosis of the applied preparations increases the efficiency of lactose hydrolysis by 10 $15 \%$, compared with the use of only one enzyme GODO-YNL2.

Simultaneous use of acidophilic starter and enzyme not only increases the efficiency of lactose hydrolysis, but also has the following advantages:

- The possibility of enriching whey ice cream with probiotic culture; 


\section{- Food Technology}

- Providing ice cream with original organoleptic properties;

- Formation of a thick consistency and increasing of resistance to melting of ice cream in the presence of viscous exopolysaccharides produced by $l$. Acidophilus.

\section{Water activity in fermented and unfermented whey concentrates with different dry matter content}

The obtained products of lactose hydrolysis, in particular monosaccharides, will undoubtedly affect the osmotic pressure of the aqueous phase of ice cream and, accordingly, a slight decrease in the cryoscopic temperature of the mixtures. Shifting the cryoscopic temperature to values lower than $-4{ }^{\circ} \mathrm{C}$ is not desirable for ice cream, which is subjected to further low-temperature processing and long-term storage. Too low cryoscopic temperature reduces the melting resistance of ice cream (Polischuk et al., 2019). To check the effect of lactose hydrolysis products on the osmotic pressure of the aqueous phase of ice cream, the water activity (Aw) of fermented and unfermented concentrates of reconstituted whey with different dry matter content was studied (see Figure 1).

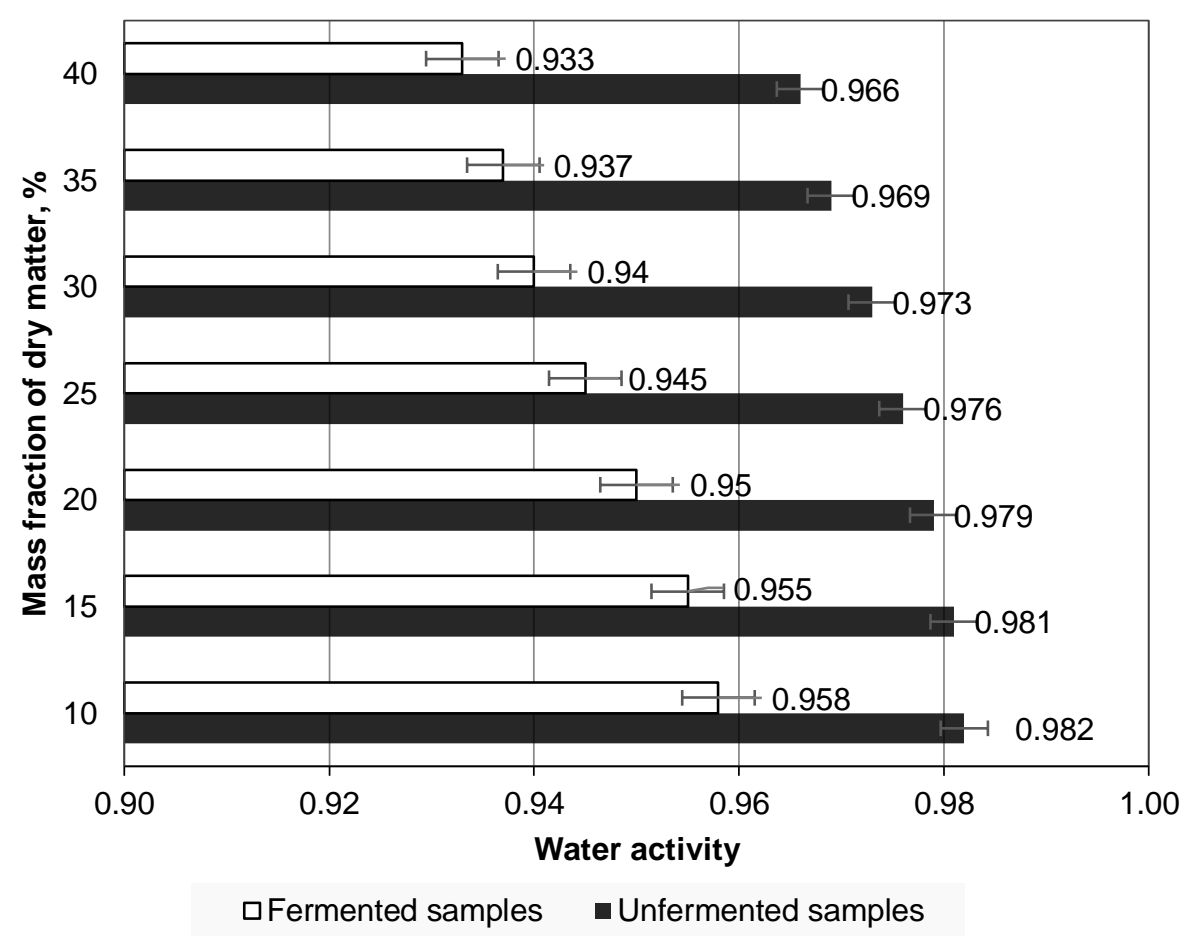

Figure 1. Water activity of unfermented and fermented samples of reconstituted demineralized sweet whey with different dry matter content

According to figure 1, the predictable and rather insignificant influence of monosaccharides on the state of water in the studied samples becomes clear (Polischuk et al., 2019). A slight decrease in Aw in fermented whey concentrates due to lactose hydrolysis will to some extent affect the processes of formation of ice cream physicochemical parameters as 
a polydisperse food system. Therefore, in further work, it will be necessary to investigate the cryoscopic temperature of ice cream samples based on hydrolyzed concentrates of demineralized whey.

\section{Degree of substitution of sugar for lactose hydrolysis products}

From a physiological point of view, the feeling of sweetness is a general feeling of appetite that occurs when sweeteners stimulate specialized receptor proteins. Sweet foods, including ice cream, are energetically rich not only because of the presence of sugar itself but also because it is usually combined with fat. Even small amounts of sugar and fat together can provide a disproportionate amount of energy (Trumbo et al., 2021). Therefore, low-fat ice cream with lower sugar content will have increased demand from consumers.

It has previously been suggested that the need for sugar in ice cream may be reduced due to the greater degree of sweetness of hydrolyzed whey concentrates compared to nonhydrolyzed concentrates. Therefore, the sweetness degree of concentrates with different dry matter content was recalculated depending on the degree of lactose hydrolysis (Table 3) (Trumbo et al., 2021). The values of relative sweetness for lactose were taken as 0.16 , and the values of the relative sweetness of glucose and galactose were 0.73 and 0.32 , respectively.

\section{Relative sweetness of concentrates from demineralized whey at different dry matter content and degree of lactose hydrolysis}

\begin{tabular}{|c|c|c|c|c|c|c|c|c|c|c|c|}
\hline $\begin{array}{c}\text { Mass } \\
\text { fraction } \\
\text { of dry } \\
\text { matter } \\
\text { in whey, } \\
\mathbf{\%}\end{array}$ & $\mathbf{0}$ & $\mathbf{1 0}$ & $\mathbf{2 0}$ & $\mathbf{3 0}$ & $\mathbf{4 0}$ & $\mathbf{5 0}$ & $\mathbf{6 0}$ & $\mathbf{7 0}$ & $\mathbf{8 0}$ & $\mathbf{9 0}$ & $\mathbf{1 0 0}$ \\
\hline $\mathbf{1 0}$ & 0,012 & 0,015 & 0,017 & 0,020 & 0,023 & 0,025 & 0,028 & 0,031 & 0,033 & 0,036 & 0,039 \\
\hline $\mathbf{2 0}$ & 0,024 & 0,029 & 0,034 & 0,040 & 0,045 & 0,051 & 0,056 & 0,061 & 0,067 & 0,072 & 0,078 \\
\hline $\mathbf{3 0}$ & 0,036 & 0,044 & 0,052 & 0,060 & 0,068 & 0,076 & 0,084 & 0,092 & 0,100 & 0,108 & 0,117 \\
\hline $\mathbf{4 0}$ & 0,047 & 0,058 & 0,069 & 0,080 & 0,091 & 0,101 & 0,112 & 0,123 & 0,134 & 0,145 & 0,155 \\
\hline
\end{tabular}

According to the results of the calculation, the following is established. In the composition of milk-based ice cream, the sugar content is about $15 \%$, and the estimated content of hydrolyzed whey concentrates can reach $50-80 \%$. Therefore, on the example of the use of $30 \%$ fermented whey concentrate, to maintain the conventional degree of sweetness in ice cream it is possible to reduce the sugar content to $70.5-83.5 \%$.

Thus, another, and very significant advantage of using fermented concentrates of demineralized whey in ice cream has been proved. This advantage opens up new possibilities for obtaining low-calorie ice cream, low in sugar and fat, enriched with whey proteins and probiotics, with high resistance to melting and a creamy consistency.

The prospect of further research is the development of scientifically sound formulations for low-calorie ice cream with high nutritional value based on hydrolyzed concentrates of reconstituted fermented whey. After establishing the lactose content in such ice cream, it can be attributed either to the lactose-free product (lactose $<0.1 \%$ ) or to the product with reduced lactose content (lactose $<1 \%$ ). With the increased content of whey proteins, the biological 
value of the new product and its organoleptic and physicochemical parameters will be studied.

\section{Conclusions}

1. To enrich the ice cream with whey proteins, fermented concentrates of reconstituted demineralized sweet whey were selected, which can be not only a source of biologically complete proteins, but also perform the function of sweeteners and contain probiotics, improve the quality of the finished product.

2. Rational regimes of lactose enzymolysis in concentrates of demineralized whey with a mass fraction of dry matter from 10 to $40 \%$ were determined using the enzyme preparation GODO-YNL2 in the amount of $0.1-0.4 \%$ for the duration of the process $4 \pm 2 \mathrm{~h}$ at a temperature of $40-43{ }^{\circ} \mathrm{C}$. The degree of lactose hydrolysis under these conditions reaches $70-75 \%$.

3. The possibility of increasing the efficiency of the lactose enzymolysis process in concentrates of demineralized whey to $80-85 \%$ by combining the specific action of the enzyme preparation GODO-YNL2 and starter based on L. acidophilus has been proved.

4. According to the results of calculating the relative sweetness of hydrolyzed whey concentrates at different degrees of lactose hydrolysis, the possibility of replacing them with up to $70.5-83.5 \%$ of sugar in ice cream was previously established.

\section{References}

Azari-Anpar M., Khomeiri M., Ghafouri-Oskuei H., et al. (2017), Response surface optimization of low-fat ice cream production by using resistant starch and maltodextrin as a fat replacing agent, Journal of food science and technology, 54(5), pp. 1175-1183, DOI: 10.1007/s13197-017-2492-0.

Barukčić I., Božanić R. (2008), Whey-based beverages-a new generation of diary products, Journal MLJEKARSTVO, 58(3), pp. 257-274.

Borovik T.Je., Ladodo K.S., Zaharova I.N., et al. (2014), Kislomolochnye produkty v pitanii detej rannego vozrasta, Voprosy sovremennoj pediatrii, 13(1), pp. 89-95.

Chauhan J. M., Lim S-Y., Powers J. R., et al. (2010), Short Communication: Low-Fat Ice Cream Flavor Not Modified by High Hydrostatic Pressure Treatment of Whey Protein Concentrate, Journal of Dairy Science, 93 (4), pp. 1452-1458, DOI: 10.3168/jds.2009-2688.

Drgalic I., Tratnik L., Božanić R. (2005), Growth and survival of probiotic bacteriain reconstituted whey, Dairy Science \& Technology,85(3), pp. 171-179, DOI: 10.1051/lait:2005009.

El-Zeini H., Moneir E., Mostafa A., et al. (2016), Effect of Incorporating Whey Protein Concentrate on Chemical, Rheological and Textural Properties of Ice Cream, Food Process Technologies, 7(546), DOI: 10.4172/2157-7110.1000546.

Goff H. D., Hartel R. W. (2013), Ice cream. Springer Science \& Business Media, pp. 75-443, DOI: 10.1007/978-1-4614-6096-1.

Hnitsevych V., Chykun N., Honchar Yu. (2017), Kinetyka fermentolizu laktozy molochnoi syrovatky, Tovary $i$ rynky, 2(1), Available at: http://nbuv.gov.ua/UJRN/tovary_2017_2\%281\%29_12. 
Kuzmyk U., Marynin A., Svyatnenko R., et al. (2021), Prospects of use of vegetable raw materials in the technology of sour-milk dessert, EUREKA: Life Sciences, (3), pp. 2935, DOI: 10.21303/2504-5695.2021.001848.

Lisak K., Matijević B., Božanić R., et al. (2011), Impact of enzymatic hydrolyzed lactose on fermentation and growth of probiotic bacteria in whey, Journal MLJEKARSTVO, 61(2), pp. 154-160.

Livney Y. D., Donhowe D.P., Hartel R.W. (2007), Influence of temperature on crystallization of lactose in ice-cream, International Journal of Food Science \& Technologies, 30(3), pp. 311-320, DOI: 10.1111/j.1365-2621.1995.tb01380.x.

Mjalo S.V., Gavrilova N.B., Voronova T.D. (2005), Issledovanie processa gidroliza molochnogo sahara jenzimaticheskim i mikrobiologicheskim sposobami, Polzunovskij al'manah, 1, pp. 87-94.

Nadtochij L.A., Jakovchenko N.V., Abdullaeva M.S., et al. (2016), Razrabotka tehnologii i sostava vysokobelkovoj smesi morozhenogo, Nauchnyj zhurnal NIU ITMO, 4, pp. 50-57, DOI: 10.17586/2310-1164-2016-9-4-50-57.

Özdemir C., Arslaner A., Özdemir S., et al. (2018), Ice-Cream Production from Lactose-Free UHT Milk, Journal of Food Science and Engineering, 8, pp. 210-214, DOI: 10.17265/2159-5828/2018.05.003.

Patel M.R., Baer R.J., Acharya M.R. (2006), Increasing the Protein Content of Ice Cream, Journal of Dairy Science, 89(5), pp. 1400-1406, DOI: 10.3168/jds.S00220302(06)72208-1.

Polischuk G., Bass O., Osmak T., et al. (2019), Cryoprotective ability of starch syrup in the composition of aromatic and fruit-berry ice cream, Ukrainian Food Journal, 8(2), pp. 239-248, DOI: 10.24263/2304-974X-2019-8-2-4.

Polishchuk G., Breus N., Shevchenko I. et al. (2020), Determining the effect of casein on the quality indicators of cream with different fat content, Eastern-European Journal of enterprise technologies, 4(11), DOI: 10.15587/1729-4061.2020.208954.

Robert T., Marshall H., Goff D. et al. (2003), Ice Cream, Springer US, DOI: 10.1007/978-1-4615-0163-3.

Rosolen M., Gennari A., Volpato G. et al. (2015), Lactose Hydrolysis in Milk and Dairy Whey Using Microbial $\beta$-Galactosidases, Enzyme Research, 1(2), pp. 1-7, DOI: $10.1155 / 2015 / 806240$.

Sangwan V., Tomar S. K., Ali B. et al. (2015), Production of $\beta$-galactosidase from streptococcus thermophilus for galactooligosaccharides synthesis, Journal of food science and technology, 52(7), pp. 4206-4215, DOI: 10.1007/s13197-014-1486-4.

Schmidt C., Mende S., Jaros D. et al. (2016), Fermented milk products: effects of lactose hydrolysis and fermentation conditions on the rheological properties, Dairy Science \& Technology, 96(2), pp. 199-211, DOI: 10.1007/s13594-015-0259-9.

Sharma P., Trivedi N., Gat Y. (2017), Development of functional fermented whey-oatbased product using probiotic bacteria, Biotech, 7(4), pp. 1-8, DOI: 10.1007/s13205-0170906-3.

Sleator R. D., Hill C. (2002), Bacterial osmoadaptation: the role of osmolytes in bacterial stress and virulence, FEMS microbiology reviews, 26(1), pp. 49-71, DOI: 10.1111/j.1574-6976.2002.tb00598.x.

Sokolovskaja L.N., Rakova E.A., Dymar O.V. (2017), Fermentativnyj gidroliz v tehnologii sgushhennoj syvorotki, Produkt BY, 7, pp. 55-59.

Stehlik-Tomas V., Grba S., Stanzer D., et al. (2001), Hydrolysis of lactose with -Dgalactosidase, Journal MLJEKARSTVO, 51 (3), pp. 187-196. 


\section{— Food Technology —}

Teles F. F., Young C. K., Stull J. W. (1978), A method for rapid determination of lactose, Journal of Dairy Science,61(4), pp. 506-508, DOI: 10.3168/jds.S00220302(78)83626-1.

Tomovska J., Gjorgievski N., Makarijoski B. (2016), Examination of pH, Titratable Acidity and Antioxidant Activity in Fermented Milk, Journal of materials Science and Engineering, Journal of Materials Science and Engineering A, 6(11), pp. 326-333, DOI: 10.17265/2161-6213/2016.11-12.006.

Trumbo P. R., Appleton K. M., De Graaf K., et al. (2021), Perspective: measuring sweetness in foods, beverages, and diets: toward understanding the role of sweetness in health, Advances in Nutrition, 12(2), pp. 343-354, DOI: 10.1093/advances/nmaa151. 